www.czasopisma.marszalek.com.pl/pl/10-15804/npw

\author{
Natalia Gburzyńska \\ Uniwersytet Mikołaja Kopernika w Toruniu \\ ORCID ID: https://orcid.org/0000-0002-1091-4741
}

\title{
Rynek turystyczny w Kazachstanie - wybrane zagadnienia
}

\section{Tourist market in Kazakhstan - selected issues}

\section{Abstract}

This article concerns the modern tourist market in Kazakhstan. I focused to a large extent on the indications of the tourist industry's characteristics in this country as well as the potential chances and threats that may be encountered in this area of the economy. The conclusions contained in the publication were based not only on source materials, but also on the author's personal observations and memories of friends of the traveler. The aim of the article was to draw attention to the unusual tourism richness that can be observed by traveling through this country of Central Asia, as well as changing the stereotypical view of Kazakhstan.

Keywords: Kazakhstan, the image of the state, tourism, Central Asia, Astana

\section{Туристический рынок в Казахстане - избранные вопросы}

\section{Аннотация}

Данная статья касается современного туристического рынка Казахстана. Я сосредоточилась в основном на показателях туристической индустрии в этой стране, а также на потенциальных шансах и угрозах, которые могут встретиться в этой области экономики. Выводы, содержащиеся в публикации, основывались не только 
на исходных материалах, но и на личных наблюдениях автора и воспоминаниях друзей. Целью статьи было привлечь внимание к необычному туристическому богатству, которое можно наблюдать, путешествуя по этой стране Центральной Азии, а также изменить стереотипный взгляд на Казахстан.

Ключевые слова: Казахстан, государственный имидж, Центральная Азия, Астана

D o rozpadzie Związku Radzieckiego nowo powstałe republiki musiały rozpocząć proces formowania się i budowania swojej tożsamości. Wiele elementów, takich jak gospodarka, kultura, sprawy społeczne, edukacja, polityka lokalna i państwowa wymagało usprawnienia, a nawet wprowadzenia na nowe tory. Republikę Kazachstan można wskazać jako jeden z tych podmiotów, które najlepiej poradziły sobie $\mathrm{z}$ wprowadzeniem w życie tych zasad.

Powstanie w 1991 roku nowych państw (w tym m.in. Republiki Kazachstanu) dokonało się poprzez stworzenie nowej rzeczywistości i zbudowanie nowych elit politycznych, skupionych na budowaniu odrębnych państw (Wallas, 2016, s. 5).

Z powstaniem Kazachstanu, który znamy współcześnie, wiązało się jednak duże wyzwanie - jak już wspomniano nie tylko w postaci transformacji ustrojowej - ale także w zakresie stworzenia narodu. Piotr Grochmalski w swojej monografii pt. Kazachstan wskazuje zresztą na podobieństwo w tej kwestii Ukrainy i Kazachstanu, przytaczając słowa Andrew Wilsona, iż Ukraina to „państwo niespodziewane. Przede wszystkim z tej przyczyny, że powstanie niepodległego państwa ukraińskiego w 1991 roku było ogromnym zaskoczeniem dla kancelarii dyplomatycznych, uniwersytetów i giełd zachodnich - niespodzianką, z którą Zachód nie zdążył się zresztą jeszcze do końca oswoić, tym bardziej, że wziąwszy pod uwagę etniczne, językowe i religijne zróżnicowanie współczesnej Ukrainy, istniało wiele poważnych przyczyn, by uważać ten kraj za wyjątkowo mało prawdopodobnego kandydata do suwerennego bytu państwowego" (Grochmalski, 2006, s. 18). Analogiczną opinię P. Grochmalski wyraża odnośnie do Kazachstanu, wskazując że państwo to często jest traktowane przez zachodnie środowiska naukowe po macoszemu i udzielane jest mu niewiele uwagi. 
Przeciętnemu Europejczykowi Kazachstan kojarzy się z państwem zacofanym, biednym, w którym nie ma nowoczesnych miast, nowatorskich technologii, a ludzie żyją bardzo skromnie, a wręcz biednie. Także kazachska gospodarka wydaje się zamknięta na nowatorskie technologie. W swoich rozważaniach chciałabym udowodnić, że takie postrzeganie tej byłej radzieckiej republiki jest bardzo niesprawiedliwe - w Kazachstanie możemy zobaczyć wiele pięknych i nowoczesnych budynków, a mieszkańcy tego państwa mają powody do dumy.

Region Azji Centralnej to obszar niezwykle interesujący, a w polskiej nauce wciąż nie do końca zbadany. Zarówno w politologii, jak i stosunkach międzynarodowych coraz częściej mówi się o tym obszarze, jednakże głównie w odniesieniu do spraw związanych z gospodarką czy polityką. Nauka jednak nie powinna ograniczać się tylko do tych dwóch aspektów, dlatego została podjęta niniejsza próba zbadania kwestii związanych ze sferą kulturalno-turystyczną. Należy wierzyć, że poniższe rozważania choć w niewielkim stopniu wypełnią ten obszar badawczy w nauce. Metodą, jaką w głównej mierze została wykorzystana podczas pracy nad tym artykułem, była metoda analizy treści. Metodą pomocniczą do niej była metoda empiryczna.

Warto tutaj zaznaczyć, że - zwłaszcza w drugiej części artykułu - wiele jest odniesień zarówno do mojej podróży do Kazachstanu, która odbyła się w październiku 2017 roku, jak i do wrażeń, jakie to państwo wywarło na innych - znanych mi - turystach. Siłą rzeczy zatem przytoczone opinie są subiektywne, momentami mogą nawet stwarzać wrażenie jakby zaczerpnięte były z dziennika podróży. Mam tę świadomość, jednakże taki był od początku zamysł, który towarzyszył mi podczas pracy nad niniejszym artykułem. Wierzę jednak, że takie osobiste odniesienia i opinie staną się pozytywnym akcentem moich rozważań.

W niniejszym artykule przedmiotem badań będzie obecna sytuacja na rynku turystycznym w Kazachstanie, pomimo świadomości, że zaszłości historyczne wpływają na prowadzoną politykę oraz wizerunek państwa na świecie. Uwaga zostanie skupiona na wskazaniu elementów, które mogą zmienić stereotypowe postrzeganie Kazachstanu - z punktu widzenia rynku turystycznego oraz europejskich turystów. Być może dzięki temu przestanie się on kojarzyć z państwem wykreowanym w fikcyjnym świecie Borata 
Sagdijewa - bohatera filmu Borat: podpatrzone w Ameryce, aby Kazachstan rósł w siłę, a ludziom żyło się dostatniej.

Cel niniejszego artykułu to także wskazanie cech kazachskiego ${ }^{1}$ rynku turystycznego, $\mathrm{z}$ uwzględnieniem walorów tego obszaru, ale i trudności z jakimi można się tam spotkać. Chciałabym wskazać nie tylko na podejmowane przez kazachski rząd działania, mające na celu promowanie branży turystycznej, ale także zaprezentować miejsca, które mogą być ciekawe dla polskich turystów. Kazachstan posiada wiele walorów, którymi może się pochwalić. Jednak musi rozbudowywać zestaw narzędzi, które umożliwią dotarcie informacji do szerszego grona potencjalnych zwiedzających.

Kierunek ten jest coraz popularniejszy w badaniach naukowych i gospodarce, coraz więcej mówi się o potencjale, jaki drzemie w kazachskich stepach i miastach. W polskiej literaturze naukowej autorzy skupiają się w znacznej mierze na zagadnieniach ekonomicznych, politycznych, czasem społecznych i kulturalnych, o turystyce i zasobach geograficznych mówi się natomiast niewiele. Uważam, że niesłusznie jest to temat pomijany.W swoich rozważaniach chcę zatem wskazać $\mathrm{z}$ jakich walorów turystycznych obywatele Kazachstanu mogą być dumni i co nas - Europejczyków - może zachwycić w tym regionie. Dowodem wzrostu popularności tego kierunku wśród turystów (także z Polski) jest chociażby fakt, że od maja 2017 roku Polskie Linie Lotnicze LOT wprowadziły bezpośrednie przeloty z Warszawy do kazachskiej stolicy. Rejsy odbywają się cztery razy w tygodniu: w poniedziałek, środę, piątek i sobotę (Nowa trasa...).

Ułatwieniem dla turystów z Polski jest także zmniejszenie liczby formalności, jakie należy załatwić przed wyjazdem - od stycznia 2017 roku

1 Przymiotnik ten będzie konsekwentnie używany w niniejszym artykule w odniesieniu do różnych sfer rzeczywistości państwowej. Mając jednak na uwadze, iż może on kojarzyć się z etniczną grupą Kazachów, tj. ludności tej narodowości (społeczeństwo państwowe natomiast składa się z obywateli różnych narodowości), konieczne wydaje się uzasadnienie $\mathrm{w}$ tym miejscu użycia powyższego przymiotnika w zastosowanej formie. Terytorium dzisiejszego Kazachstanu od dawna zamieszkiwane było przez lud nazywany Kazachami, jednakże obecnie powyższe określenie stosuje się zarówno dla potomków tamtego ludu, jak i obywateli państwa. Odrębna nazwa dla obywatela państwa - Kazachstańczyk - jest obecnie stosowana niezwykle rzadko. Podobna sytuacja dotyczy zastosowanego przymiotnika tutaj w powszechnym użyciu jest słowo „kazachski”, określenie „kazachstański” pojawia się w polszczyźnie niezwykle rzadko (Taj a Tajlandczyk, kazachski a kazachstański...). 
Polacy mogą podróżować do Kazachstanu bez konieczności wyrabiania wizy, co z pewnością jest dużą zaletą. Nasi obywatele mogą wylecieć do tego azjatyckiego państwa jedynie na podstawie ważnego paszportu, o ile nie będą przebywać na jego terytorium dłużej niż 30 dni. Ambasador Republiki Kazachstan w Polsce - Ałtaj Abibułłajew - podkreślił, że „zmiany w przepisach wizowych to wielki krok w zacieśnianiu relacji między Polską i Kazachstanem. To szansa nie tylko dla polskich przedsiębiorców, którzy planują rozwój swojego biznesu w Kazachstanie, ale również dla turystów. Azja Środkowa pozostaje nieodkryta. Zwiedzanie miast ze wspaniałą historią, uprawianie sportów zimowych, wspinaczka górska, czy wielodniowe trekkingi to jedynie część możliwości, które oferuje Kazachstan” (Pakuła, 2017).

\section{Kazachstan - nowy kierunek turystyczny?}

Bezsprzecznie jedną z gałęzi gospodarki, które sprawiły, że ekonomia kazachska rozwija się w doskonałym tempie, a jednocześnie sprawia, że państwo to prosperuje bardzo dobrze na tle innych państw Wspólnoty Niepodległych Państw, jest rozwój turystyki. Mimo wspomnianego potencjału Kazachstan na mapie turystycznej świata zaistniał dość niedawno, nie wykorzystując wszystkich swoich zasobów. Na terenie państwa znajdują się liczne parki krajobrazowe, rezerwaty przyrody oraz ponad 9 tysięcy zabytków archeologicznych i historycznych - jednakże potencjał tych atrakcji turystycznych nie jest wykorzystywany w pełni (Erdawletow, Alijewa, Makutowa, 2014, s. 296).

Posiadając tak duże możliwości zainteresowania turystów wieloma atrakcjami, zarówno rząd państwowy, jak i kazachskie prywatne firmy turystyczne mogą zaoferować różnego rodzaju formy turystyki, zaczynając od turystyki sportowej, poprzez turystykę uzdrowiskową, ekologiczną, aż do pielgrzymkowej. Jednakże ta gałąź gospodarki charakteryzuje się sezonowością, przez co nie można wykorzystać dostępnego potencjału w 100\%. Kolejnym problemem kazachskiej turystyki są ograniczenia w infrastrukturze mieszkaniowej - braki hoteli czy pensjonatów dla osób z zagranicy (zwłaszcza na obszarach słabo zaludnionych). Utrudnieniem są także braki w dostępnych środkach transportu, sposobach komunikacji czy - ogólnie rozumianej sferze obsługi. Problemem może być także rozlokowanie większych miast 
na terytorium państwa - nierzadko dotarcie z jednej większej miejscowości do kolejnej to kilka godzin podróży, a w międzyczasie nie ma na trasie niemal żadnej infrastruktury, dostępnej dla podróżujących. Wszystkie te kwestie sprawiają, że „typowy turysta” z Zachodu może zrezygnować z podróży jeszcze przed jej rozpoczęciem. Należy zatem położyć większy nacisk na budowę zaplecza turystycznego, co z pewnością przyczyniłoby się do wzrostu liczby turystów oraz ilości zostawianych przez nich pieniędzy. Jak wspominają autorzy artykułu Współczesny Kazachstan - nowy kierunek na światowym rynku turystycznym: „Z powodu braku dostatecznej uwagi i braku dbałości ze strony państwa sektor turystyczny otrzymuje zbyt mało środków, w konsekwencji czego ciągle niszczeje infrastruktura, uszczerbku doznają pomniki przyrody, kultury i historii" (Erdawletow, Alijewa, Makutowa, 2014, s. 297).

Jedną z przyczyn takiej sytuacji jest brak wsparcia ze strony państwa, które niedostatecznie skupia się na możliwościach wykorzystania potencjału (choć w ostatnich latach sytuacja ta zmienia się na korzyść, a politycy widzą potrzebę inwestycji w tym obszarze). Wiadomo bowiem, że bez wspierania inicjatyw na szczeblu państwowym niemożliwe jest zbudowanie silnej pozycji tej gałęzi gospodarki. Obowiązujące w Kazachstanie przepisy nie obejmują wszystkich problemów związanych z rozwojem turystyki, a co więcej - bardzo często skupiają się jedynie na sferze regulacji finansów oraz określaniu podstawowych obowiązków i praw turystów. Kolejnym czynnikiem, który blokuje rozwój tej dziedziny, jest brak naukowych podstaw w sferze działalności turystycznej, tj. w państwie w zasadzie nie ma instytucji i organizacji, które zajmowałyby się prognozowaniem rozwoju turystyki regionalnej i wskazałyby obszary mogące w przyszłości przynosić zyski (Erdawletow, Alijewa, Makutowa, 2014, s. 298).

Jednakże mimo wspomnianych wyżej trudności, Kazachstan ma szansę na rozwój turystyki i pełne wykorzystanie zasobów. Po pierwsze, wiąże się to z posiadaniem wielu walorów, które mogą być atrakcją dla zagranicznych turystów. Kazachska stolica - Astana - i okoliczne atrakcje (Burabaj², Korgałżyn ${ }^{3}$,

2 Osiedle typu miejskiego w Kazachstanie, znane powszechnie jako uzdrowisko klimatyczne i miejscowość turystyczna.

3 Chroniony rezerwat przyrody w pobliżu Astany. 
Karkarały $^{4}$ czy Kokczetaw ${ }^{5}$ ) posiadają wiele elementów, które mogą być interesujące dla zwiedzających. Walory turystyczne Ałmaty są gwarancją udanego wypoczynku podczas narciarskich eskapad i miejskich spacerów. W zachodniej części państwa trwają także prace nad stworzeniem międzynarodowego kurortu turystycznego. Od 2013 roku pracownicy Ministerstwa Przemysłu i Nowych Technologii prowadzą działania na rzecz wdrożenia planu rozwoju kurortu do końca 2020 roku (Erdawletow, Alijewa, Makutowa, 2014, s. 300).

Rynek turystyczny w Europie otwiera się na nowe kierunki, a w tym wypadku Kazachstan to podróżnicza nisza, w którą - moim zdaniem - warto zainwestować. Należy jednak zauważyć, że tylko $1 / 3$ ze wszystkich przyjeżdżających do Kazachstanu w ciągu każdego roku to „prawdziwi turyści”. Pozostała grupa (w dużej mierze to obywatele krajów byłego Związku Radzieckiego) poszukuje w tym państwie zatrudnienia i szansy na zapewnienie lepszego życia sobie oraz swojej rodzinie. Politycy kazachscy, odpowiedzialni za rozwój turystyki, postanowili jednak już kilka lat temu tę sytuację zmienić i zwiększyć atrakcyjność kazachskiego rynku podróżniczego oraz perspektywy poznania kultury oraz atmosfery kazachskich stepów. Jak wskazuje Aneta Wieczerzak-Krusińska, „celem administracji prezydenta Nazarbajewa jest potrojenie obecnej liczby zwiedzających (czyli osiągnięcie poziomu ok. 5.,5 mln turystów rocznie) do 2023 roku” (Wieczerzak-Krusińska, 2017). Wizytówką turystyczną kraju ma być oczywiście Astana - lśniąca złotem, nowoczesna, z futurystyczną architekturą.

Przewodniczący kazachskiego Senatu, Kassym-Zhomart Tokayev, w trakcie spotkania z przedstawicielami światowych mediów podkreślał, że Kazachowie chętnie wyjeżdżają za granicę, jednak zagraniczni turyści w umiarkowanym stopniu odwiedzają Kazachstan, Zjawisko to stało się motywacją do podjęcia działań, mających na celu poprawę sytuacji wewnętrznej. Polityk wskazał także, że wprowadzone zostały narzędzia promowania zalet kazachskich terenów zarówno dla potencjalnych turystów, jak i inwestorów zainteresowanych zakładaniem biznesu w Azji Centralnej. „Nie wygramy z kierunkami europejskimi w wyścigu na dziedzictwo kulturowo-historyczne.

4 Miasto w środkowym Kazachstanie, w pobliżu którego znajduje się popularny w całym państwie Park Narodowy o tej samej nazwie.

5 Miasto w Kazachstanie nad jeziorem Kopa. W mieście działają liczne muzea i instytucje kulturalne. Jest to także jedno z największych skupisk Polaków w Kazachstanie. 
Naszym magnesem ma być turystyka ekologiczna i etnograficzna. Rozległe terytorium Kazachstanu pozwala wejść turyście w skórę prawdziwego nomada, który, przemieszczając się, jest w stanie zobaczyć prawie wszystkie strefy klimatyczne i formy krajobrazu, np. tajgę, pustynię, półpustynię czy step" - podkreślił Tokayev (Wieczerzak-Krusińska, 2017).

W tym miejscu należy także podkreślić, że rząd kazachski podjął w ostatnich latach szereg inicjatyw, mających na celu wzmocnienie branży turystycznej oraz promowanie tego terenu za granicą. W planach na przyszłość jest także organizowanie festiwali rodzimych produktów, np. jabłek, które mogą przyciągnąć firmy eksportowe oraz te, które zainteresowane są przetwórstwem owoców. Dodatkowo powołana została spółka państwowa „Kazakh Tourism”, stawiająca na cyfryzację branży turystycznej oraz rozwój sektora IT.W jej ramach planowane jest m.in. stworzenie narzędzi $z$ aplikacjami do planowania podróży oraz zwiększania rozpoznawalności obszarów atrakcyjnych turystycznie. Będzie można nie tylko zaplanować wyjazd, kupić bilety czy przejrzeć dostępną bazę hotelową, ale także uzyskać rabat na zwiedzanie atrakcji turystycznych, a nawet uzyskać punkty na karcie lojalnościowej dla najbardziej aktywnych użytkowników portalu, które następnie będą przeliczane na możliwe rabaty (Wieczerzak-Krusińska, 2017).

Wspomniana spółka, mimo że na rynku istnieje od niedawna, działa bardzo prężnie i podejmuje szereg inicjatyw mających na celu rozwój nie tylko gałęzi turystycznej, ale i wpływ na inne sfery, w tym związane z gospodarką. „Kazakh Tourism” - jak można przeczytać na stronie internetowej spółki - zabezpiecza rozwój tego sektora rynku, będąc jednocześnie jedyną w państwie marką menadżerską w zakresie turystyki. Jako podstawowe cele wymienione są m.in. promowanie na świecie Kazachstanu jako potencjalnego kierunku turystycznego, który będzie interesujący zarówno dla turystów z Azji, jak i innych części świata, rozwój wysokiej jakości infrastruktury turystycznej dostępnej dla zagranicznych gości oraz działania stawiające na wzrost konkurencyjności państwa pod względem atrakcyjności turystycznej oraz pozyskiwanie na ten cel zarówno rodzimych, jak i zagranicznych inwestorów (Kazakh Tourism...).

W ostatnich latach poprawę sytuacji w dziedzinie turystyki możemy obserwować w stale zwiększającej się liczbie połączeń kolejowych, lotniczych czy drogowych. Z drugiej strony nadal wiele braków można zaobserwować 
w usługach, stąd tak duże skupienie kazachskich polityków na przyciągnięciu inwestorów zainteresowanych budową siatki hoteli, lokali gastronomicznych czy miejskich toalet, zwłaszcza dostępnych cenowo dla przeciętnych turystów, którzy będą bardziej zainteresowani noclegiem w trzygwiazdkowym hotelu, niż w pięciogwiazdkowym apartamencie w samym centrum miasta. Jako plus prowadzenia biznesu na tym rynku można wskazać brak biurokracji oraz krótki okres oczekiwania na wydanie wizy czy np. pozwolenia na prowadzenie działalności, jako minus - korupcję, z którą jednak politycy starają się walczyć (Wieczerzak-Krusińska, 2017).

Kazachstan to państwo, które - z perspektywy polskiego turysty - może wydawać się dzikie i nieokiełznane. Osobiście miałam podobne skojarzenia i wylatując do Kazachstanu w październiku 2017 roku nie do końca wiedziałam czego się spodziewać po tej podróży. Co prawda podróżowałam jedynie po Astanie, więc moje postrzeganie państwa jest zapewne niepełne, jednakże w dużej mierze pokrywa się z tym, czego dowiedziałam się od innych turystów, przemierzających szlaki kazachskich miast i wsi.

Autorzy bloga Przystanek Praga/Kierunek Wschód - Łukasz Piotrowski i Martyna Nełka - spędzili w Kazachstanie wakacje 2017 roku, podróżując przez Astanę, Ałmaty, Kanion Czaryński oraz rezerwat Ałtyn-Emel. Oboje zgodnie przyznają, że zwiedzone okolice można ze śmiałością uznać za „miejsca z klimatem”, którego nie da się doświadczyć w żadnych innym państwie. Autor bloga podróż skomentował słowami: „Kazachstan kojarzy się głównie ze stepem i Boratem, że niby tam nic nie ma. A to nieprawda, jest i to ile!” (Przystanek Praga/Kierunek Wschód).

Zdaniem podróżników miejscem, które zdecydowanie warte jest odwiedzenia podczas pobytu w Kazachstanie, jest także miasto Turkiestan, położone w południowej części państwa. Jak piszą M. Nełka i Ł. Piotrowski na swoim blogu: „Turkiestan to jedno z niewielu miejsc w Kazachstanie, którego historia sięga wiele wieków wstecz. Położony niedaleko od granicy z Uzbekistanem, przypomina swoją atmosferą (i temperaturą) tamtejsze miasta - Chiwę, Samarkandę, Bucharę" (Przystanek Praga/Kierunek Wschód). Podróżnicy zwracają także uwagę, że w tym mieście - w odróżnieniu np. od Ałmaty - mieszkańcy nie rozmawiają ze sobą po rosyjsku (zdjęcia z Turkiestanu oraz innych miejsc w Kazachstanie znajdują się w załączniku do niniejszego artykułu). 


\section{Astana - futurystyczna stolica}

Podczas mojej podróży do Kazachstanu byłam bardzo ciekawa jak w rzeczywistości będzie wyglądała stolica tego państwa i na ile informacje, które wcześniej przeczytałam czy usłyszałam od znajomych pokryją się z rzeczywistością. W zasadzie zaraz po wyjściu z samolotu i opuszczeniu lotniska - w drodze do hotelu - moją uwagę zwróciły dwie kwestie. Po pierwsze, rozległość miasta i jego położenie (praktycznie w całości na płaskim terenie) oraz ogromna liczba futurystycznych form, widocznych w architekturze budynków czy mostów. Od początku jednak miasto wydawało mi się niezwykle interesujące, gdyż tak bardzo różniło się od miast (także na wschodzie Europy), które miałam już okazję odwiedzić w przeszłości.

Podczas całego pobytu w Astanie byłam także bardzo pozytywnie zaskoczona ludźmi, których spotkałam - bardzo serdecznymi i gościnnymi, którzy niemal od razu po poznaniu mnie częstowali lokalnymi przysmakami oraz oferowali pomoc w zaplanowaniu zwiedzania, podpowiadali co warto zobaczyć. Astańczycy byli bardzo otwarci na turystów i często w rozmowach podkreślali jak bardzo są dumni z tego miasta oraz z prezydenta Nazarbajewa, który przyczynił się do rozwoju państwa.

Również podczas wizyty na Uniwersytecie Nursułtana Nazarbajewa największej uczelni państwowej w kraju - spotkałam się z bardzo życzliwym przyjęciem ze strony pracowników uniwersytetu i jego biblioteki, którzy nie tylko pomagali mi odnaleźć potrzebne książki i gazety, ale także udostępniali swoje konta biblioteczne, dzięki czemu mogłam sprawnie przeglądać zasoby online.

Warto tutaj także wskazać, że sam kampus uniwersytecki oraz wspomniana biblioteka zbudowane są w bardzo nowoczesnym stylu, który przypomina budynki uczelni w Europie Zachodniej czy Stanach Zjednoczonych. Zarówno biblioteka, jak i czytelnia są doskonale wyposażone. Ponadto czytelnia czynna jest od wczesnego poranka do późnych godzin nocnych (podczas mojego pobytu były to godziny 8:00-21:45, w czasie sesji egzaminacyjnej można korzystać z zasobów bibliotecznych do północy, a w niektóre dni nawet do drugiej nad ranem). Niezależnie od pory, w jakiej korzystałam z zasobów bibliotecznych, byli tam obecni studenci. Podczas rozmów przeprowadzonych z nimi oraz pracownikami biblioteki dowiedziałam się, że 
większość osób studiujących przygotowuje się do zajęć właśnie w bibliotece i czytelni, co było dla mnie niemałym zaskoczeniem, gdyż polscy studenci raczej wybierają naukę w swoich domach. Znaczna część napotkanych przeze mnie studentów porozumiewała się ze sobą po angielsku, co także wywołało moje zaskoczenie - jak sami przyznawali chcą, aby zarówno ich uczelnia, jak i oni sami byli postrzegani jako „obywatele świata”.

Jak już wcześniej wspomniałam w Astanie moją uwagę zwróciła architektura - nowoczesne formy i futurystyczne kształty były dla mnie czymś zupełnie nieznanym. Myślę, że wielu turystów zwróciło uwagę na ten charakterystyczny typ budynków. Niejednokrotnie zresztą mówi się o Astanie jako „mieście XXI wieku” i wskazuje je jako przykład metropolii przyszłości.

Oczywiście najbardziej znaną i rozpoznawalną astańską budowlą jest wieża Bajterek (po kazachsku to słowo znaczy „wysoka topola”) - 97-metrowa stalowa konstrukcja, którą zwieńcza pozłacana kula. Według przekazów ustnych to sam prezydent Nursułtan Nazarbajew był pomysłodawcą takiego kształtu budowli, którą miał naszkicować na serwetce (Astana, czyli miasto jutra...). Niezależnie od tego czy Bajterek się komuś spodoba, czy raczej wywoła nieprzychylne komentarze, nie można mu odmówić oryginalności i charakterystycznego wyglądu.

Kolejnym wartym uwagi budynkiem w Astanie jest - wykonana w stylu postmodernistycznym - Piramida Pokoju i Pojednania, we wnętrzu której mieści się m.in. kazachski teatr operowy. Pałac został zbudowany (za cenę 58 milionów dolarów) zgodnie z poleceniem prezydenta Nazarbajewa, z okazji III Kongresu Liderów Religii Światowych i Tradycyjnych (wydarzenie to miało miejsce w dn. 1-2 lipca 2009 roku, kolejne edycje odbywają się co trzy lata właśnie w tym budynku). Wygląd budynku jest charakterystyczny - kształtem przypomina egipskie piramidy, a każda ze ścian zbudowana jest z mniejszych trójkątów równobocznych. Jest to dzieło angielskich architektów z biura architektonicznego Foster and Partners (warto tutaj wspomnieć, że założyciel firmy - Norman Foster - jest także autorem innych astańskich budynków, np. zbudowanego na kształt namiotu, największego w mieście, centrum rozrywkowo-handlowego Chan-Szatyr) (Дворец Мира и Согласия... ). Można zatem przyjąć, że prezydent Nazarbajew z pełną świadomością tworzy stołeczną architekturę w futurystycznym stylu, pokazując 
że Kazachstan nie tylko nie ma się czego wstydzić ale - co więcej - może kreować wizerunek nowoczesnej metropolii.

\section{Podsumowanie}

Współczesny Kazachstan ma do zaoferowania turystom wiele atrakcji położonych zarówno w największych miastach, jak i na słynnych stepach. Powyższy artykuł był próbą wskazania niektórych elementów w zakresie turystyki, z których obywatele kazachscy mogą być dumni, ale także zwrócenia uwagi na trudności, które są jeszcze do przezwyciężenia. Opierając się na własnych doświadczeniach oraz opiniach znajomych podróżników chciałam pokazać, że państwo to ma do zaoferowania znacznie więcej niż wydaje się przeciętnemu mieszkańcowi Europy oraz że kierunek ten jest niesłusznie pomijany we współczesnej turystyce.

Moim celem było także zwrócenie uwagi, że zainteresowania naukowe, dotyczące Kazachstanu mogą opierać się nie tylko na kwestiach gospodarczych czy politycznych, ale - co również niezwykle ciekawe - można wskazać na aspekty związane $z$ architekturą czy turystyką. Mam nadzieję, że podjęte przeze mnie rozważania będą przyczynkiem nad dalszym badaniem tego regionu.

\section{MGR NATALIA GBURZYŃSKA}

Wydział Politologii i Studiów Międzynarodowych

Uniwersytet Mikołaja Kopernika w Toruniu

ul. Batorego 39 L, 87-100 Toruń

e-mail: natalia.gburzynska@op.pl

\section{Bibliografia}

Erdawletow, S., Alijewa, Ż.N., Mukatowa, D.M. (2014). Współczesny Kazachstan - nowy kierunek na światowym rynku turystycznym. W: B. Krakowiak, J. Latosińska (red.). Przeszłość, teraźniejszość i przyszłość turystyki. Warsztaty z Geografii $i$ Turyzmu. Łódź: Wydawnictwo Uniwersytetu Łódzkiego.

Grochmalski, P. (2006). Kazachstan. Toruń: Wydawnictwo Uniwersytetu Mikołaja Kopernika.

Kazachstan: Astana czyli miasto jutra. (2018, 3 sierpnia). Pobrane z: http://www.national-geographic.pl/ludzie/miasto-jutra [dostęp: 15.09.2018]. 
Kazakh Tourism, http://qaztourism.kz [dostęp: 8.02.2019].

Marszałek-Kawa, J. (red.). (2010). Militarne i gospodarcze determinanty państwowości azjatyckiej. Toruń: Wydawnictwo Adam Marszałek.

Nowa trasa PLL LOT: polecimy bezpośrednio do Astany. Pobrane z https://www.fly4free. $\mathrm{pl} /$ nowa-trasa-pll-lot-polecimy-bezposrednio-do-astany-bilety-w-sprzedazy/ [dostęp: 15.09.2018].

Pakuła, J. (2017, 3 stycznia). Do Kazachstanu bez wizy. Pobrane z: http://www.polska-azja.pl/j-pakula-do-kazachstanu-bez-wizy/ [dostęp: 16.09 2018].

Przystanek Praga/Kierunek Wschód. Pobrane z: https://www.facebook.com/PrzystanekPragaKierunekWschod/?ref=br_rs [dostęp: 16.09.2018].

Taj a Tajlandczyk, kazachski a kazachstański, czyli o nazwach członków narodowości, nazwach obywateli i przymiotnikach. W: Dobry słownik, https:/dobryslownik.pl/ slowo/kazachstański/20487/, [dostęp: 10.02.2019].

Wallas, T. (2016). Uwarunkowania regionalne i międzynarodowe w kontekście polityki Unii Europejskiej wobec Azji Centralnej. W: R. Fiedler, T. Wallas (red.). Unia Europejska wobec Azji Centralnej. Uwarunkowania regionalne i międzynarodowe. Poznań: Fundacja na rzecz Czystej Energii.

Wieczerzak-Krusińska, A. (2017, 13 listopada), Kazachstan czeka na podróżników, Rzeczpospolita, pobrane z: https://www.rp.pl/artykul/1344940-Kazachstan-czeka-na-podroznikow.html [dostęp: 21.09.2018].

Двореи, Мира и Согласия. Pobrane z: http://astana-piramida.kz [dostęp: 21.09.2018].

\section{Załączniki}

Fot. 1. Wnętrze metra w Ałmaty. Zdjęcie pobrane za zgodą autorów ze strony: https://www. facebook.com/PrzystanekPragaKierunekWschod/ [dostęp: 14.09.2018].

Fot. 2. Jezioro w Kanionie Czaryńskim w Kazachstanie. Zdjęcia pobrane za zgodą autorów ze strony https://www.facebook.com/PrzystanekPragaKierunekWschod/ [dostęp: 14.09.2018].

Fot. 3. Kanion Czaryński w Kazachstanie. Zdjęcia pobrane za zgodą autorów ze strony: https://www.facebook.com/PrzystanekPragaKierunekWschod/ [dostęp: 14.09.2018].

Fot. 4. Turkiestan.

Fot. 5. Budynek główny Uniwersytetu im. Nursułtana Nazarbajewa w Astanie. Źródło: archiwum prywatne autorki (październik 2017 r.).

Fot. 6. Holl główny Uniwersytetu im. N. Nazarbajewa, prowadzący m.in. do Biblioteki i Czytelni. Źródło: archiwum prywatne autorki (październik 2017 r.).

Fot. 7. Wieża Baiterek. Źródło: portal podróżniczy Travelin data [dostęp: 16.09.2018].

Fot. 8. Piramida Pokoju i Pojednania. Źródło: portal podróżniczy Travelin data [dostęp: 16.09.2018]. 


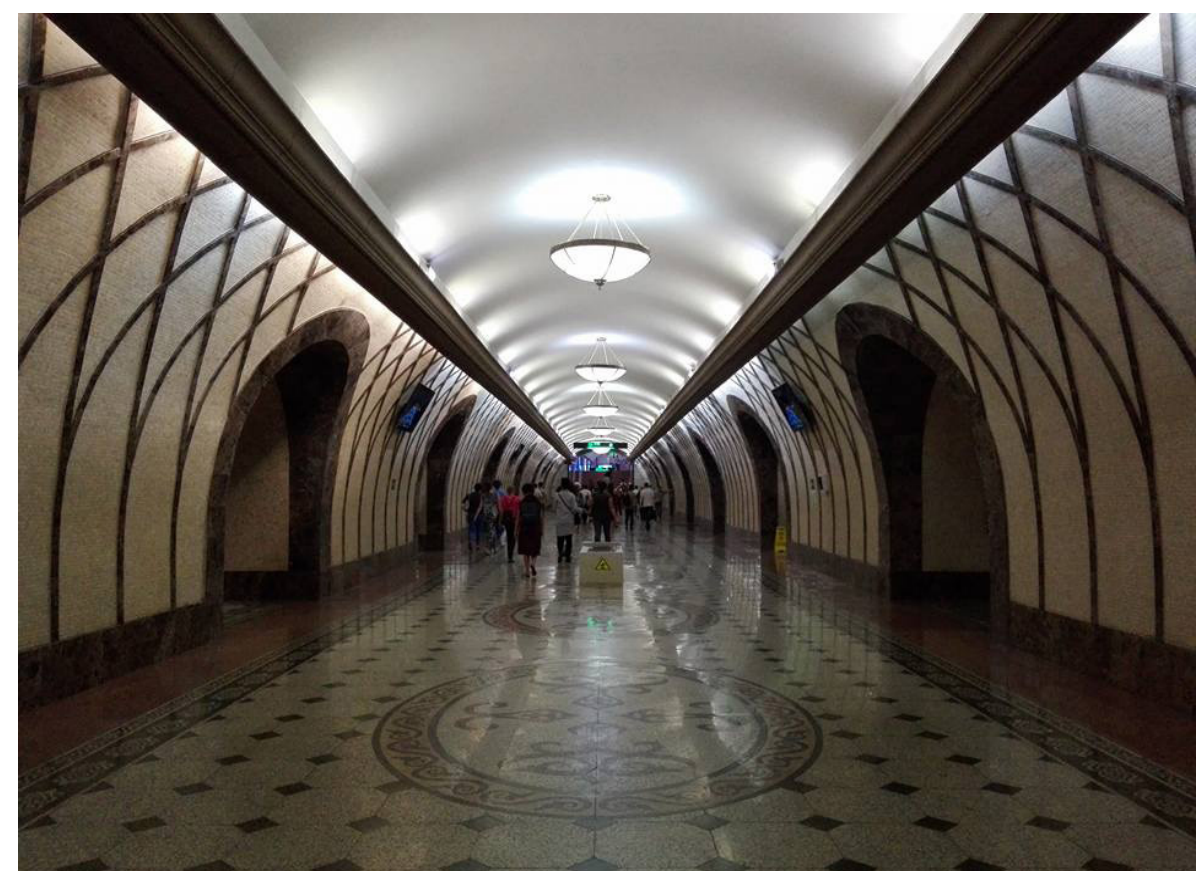

Fot. 1. Wnętrze metra w Ałmaty. Zdjęcie pobrane za zgodą autorów ze strony https:// www.facebook.com/PrzystanekPragaKierunekWschod/ [dostęp: 14.09.2018].

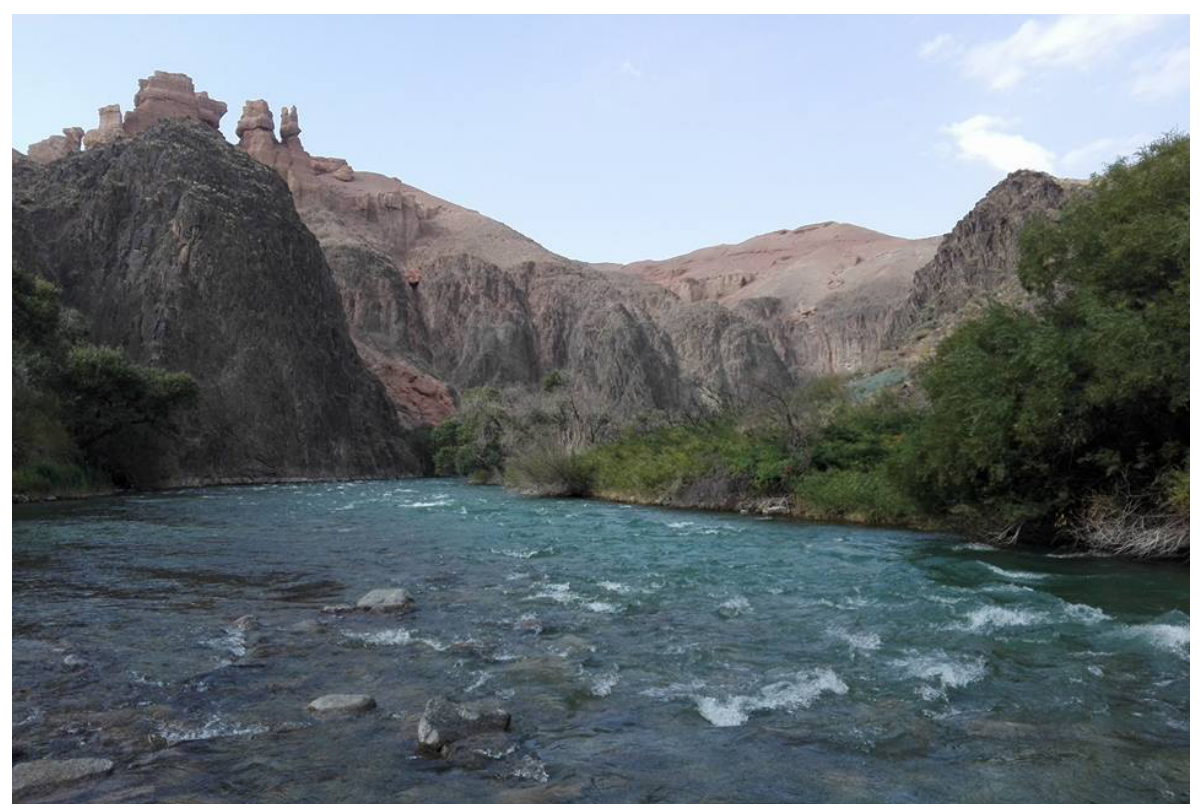

Fot. 2. Jezioro w Kanionie Czaryńskim w Kazachstanie. Zdjęcia pobrane za zgodą autorów ze strony https://www.facebook.com/PrzystanekPragaKierunekWschod/ [dostęp: 14.09.2018]. 


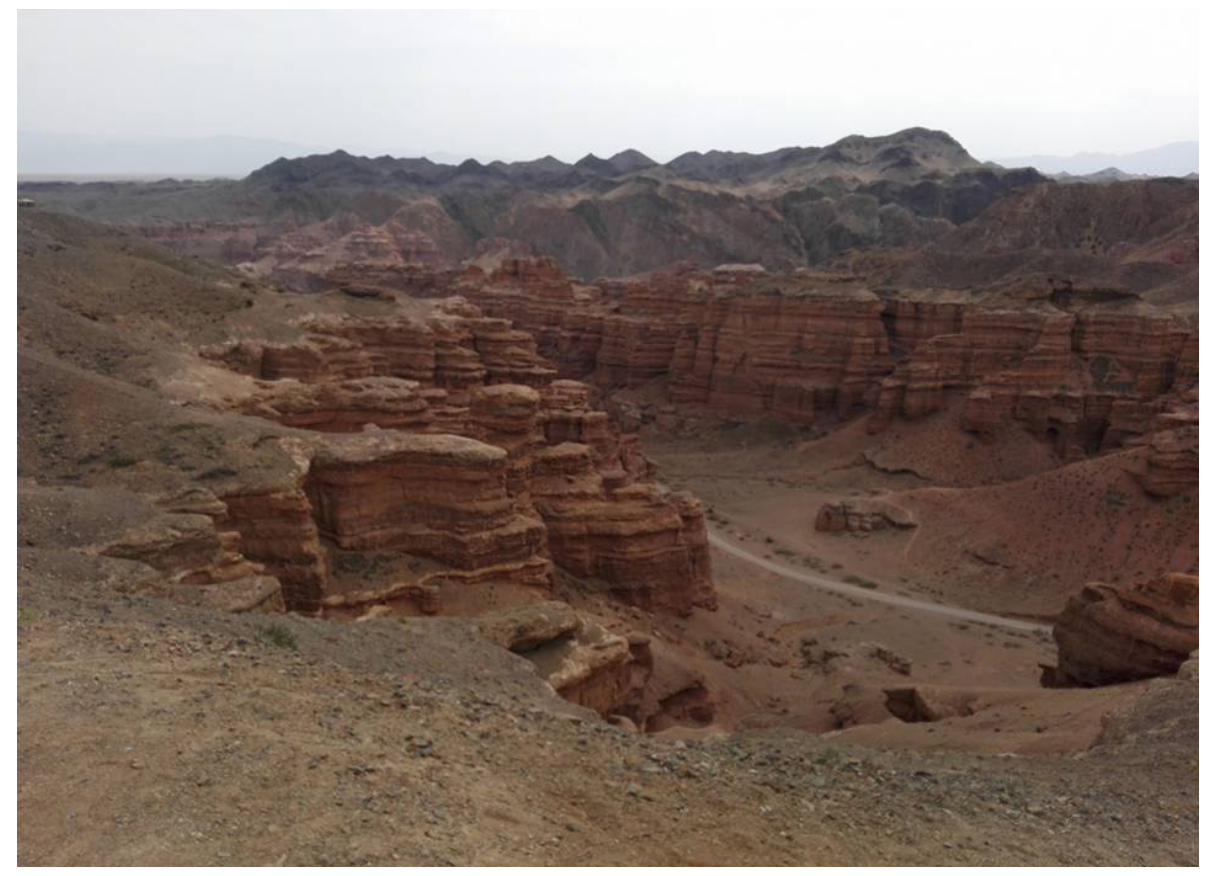

Fot. 3. Kanion Czaryński w Kazachstanie. Zdjęcia pobrane za zgodą autorów ze strony: https://www.facebook.com/PrzystanekPragaKierunekWschod/ [dostęp: 14.09.2018].

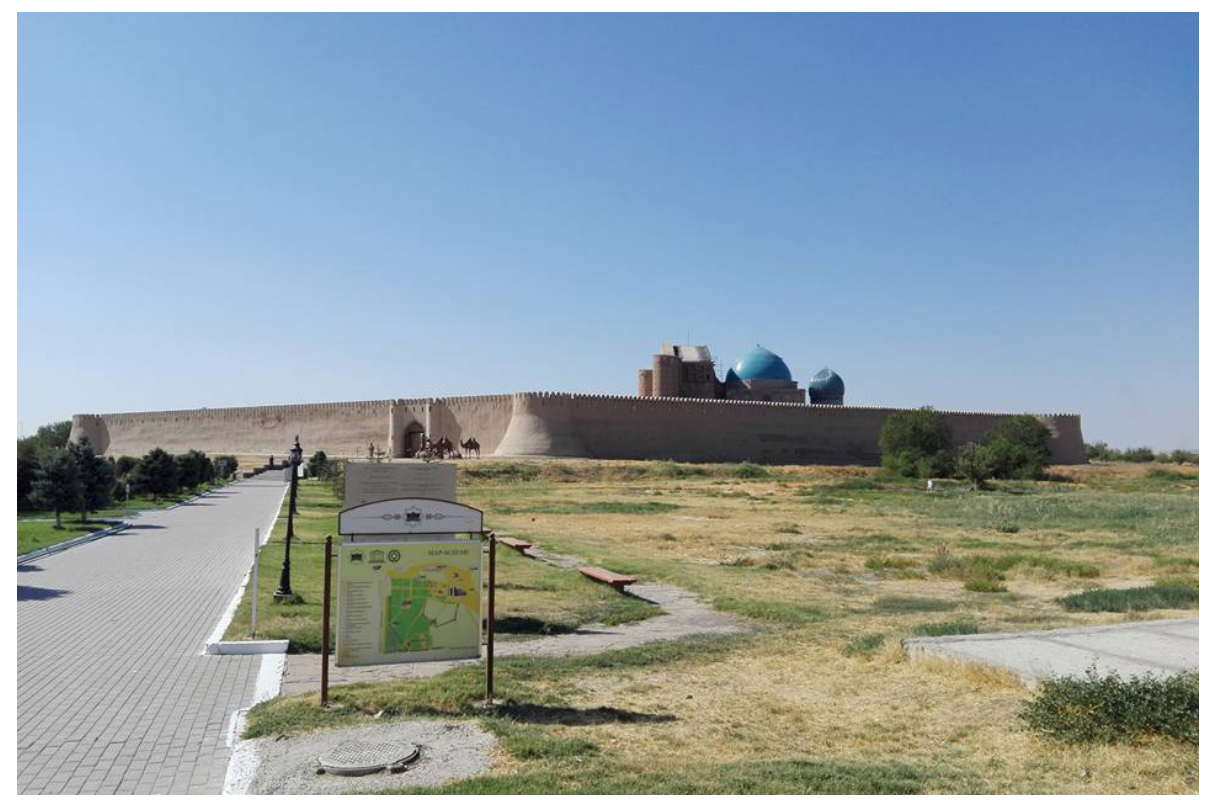

Fot. 4. Turkiestan. 


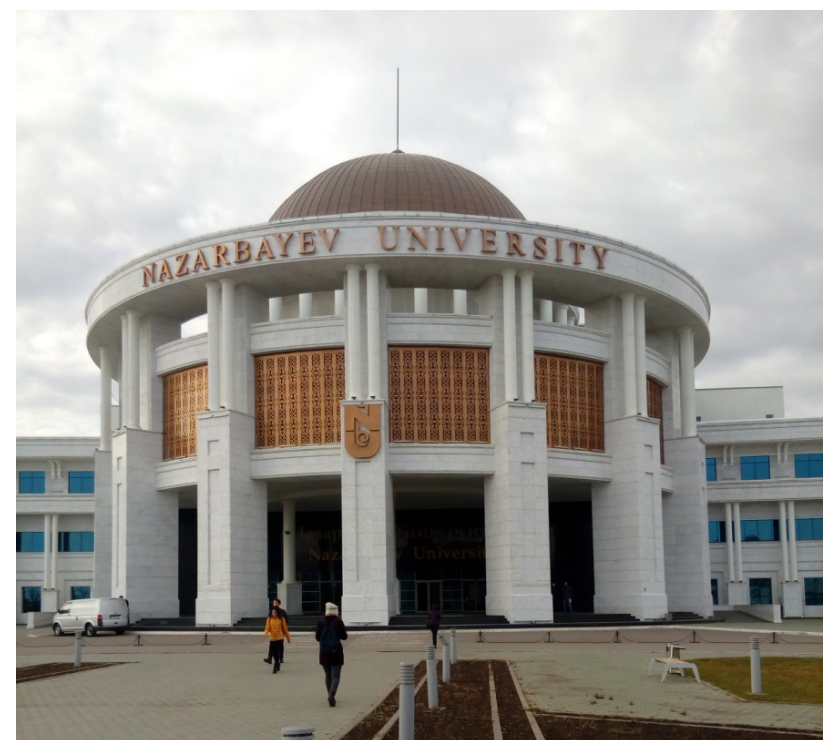

Fot. 5. Budynek główny Uniwersytetu im. Nursułtana Nazarbajewa w Astanie. Źródło: archiwum prywatne autorki (październik 2017 r.).

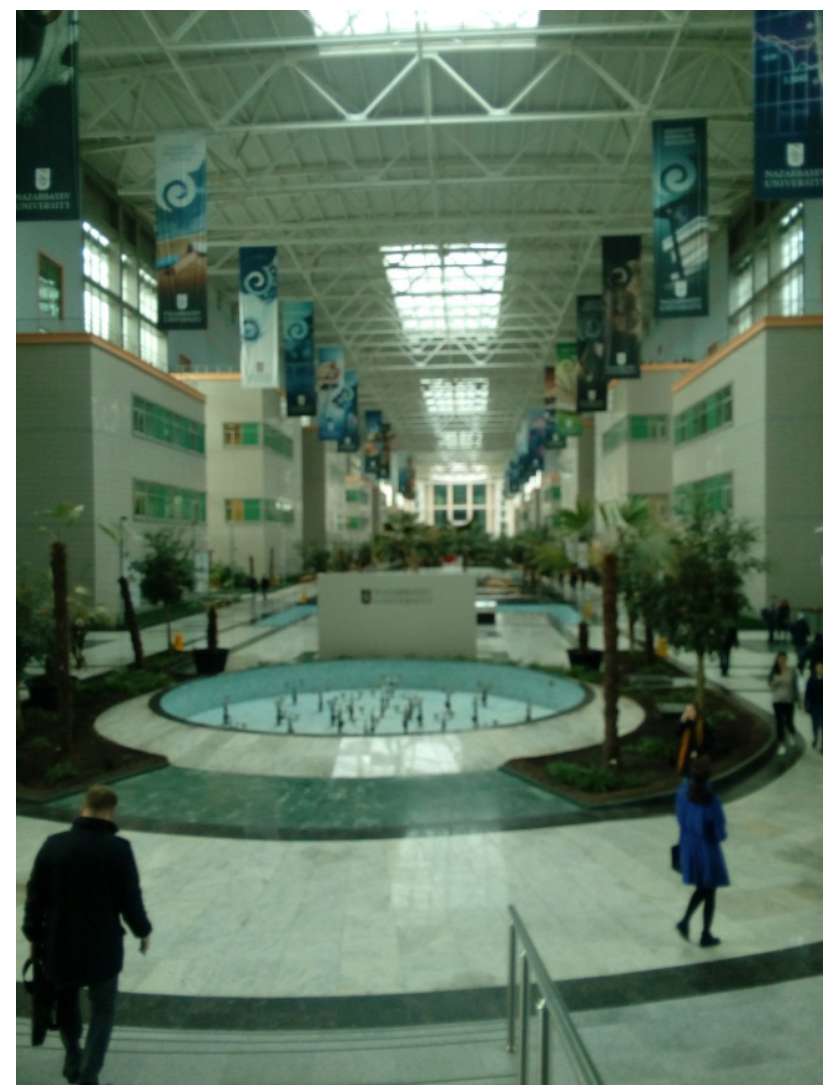

Fot. 6. Holl główny Uniwersytetu im. N. Nazarbajewa, prowadzący m.in. do Biblioteki i Czytelni. Źródło: archiwum prywatne autorki (październik 2017 r.). 


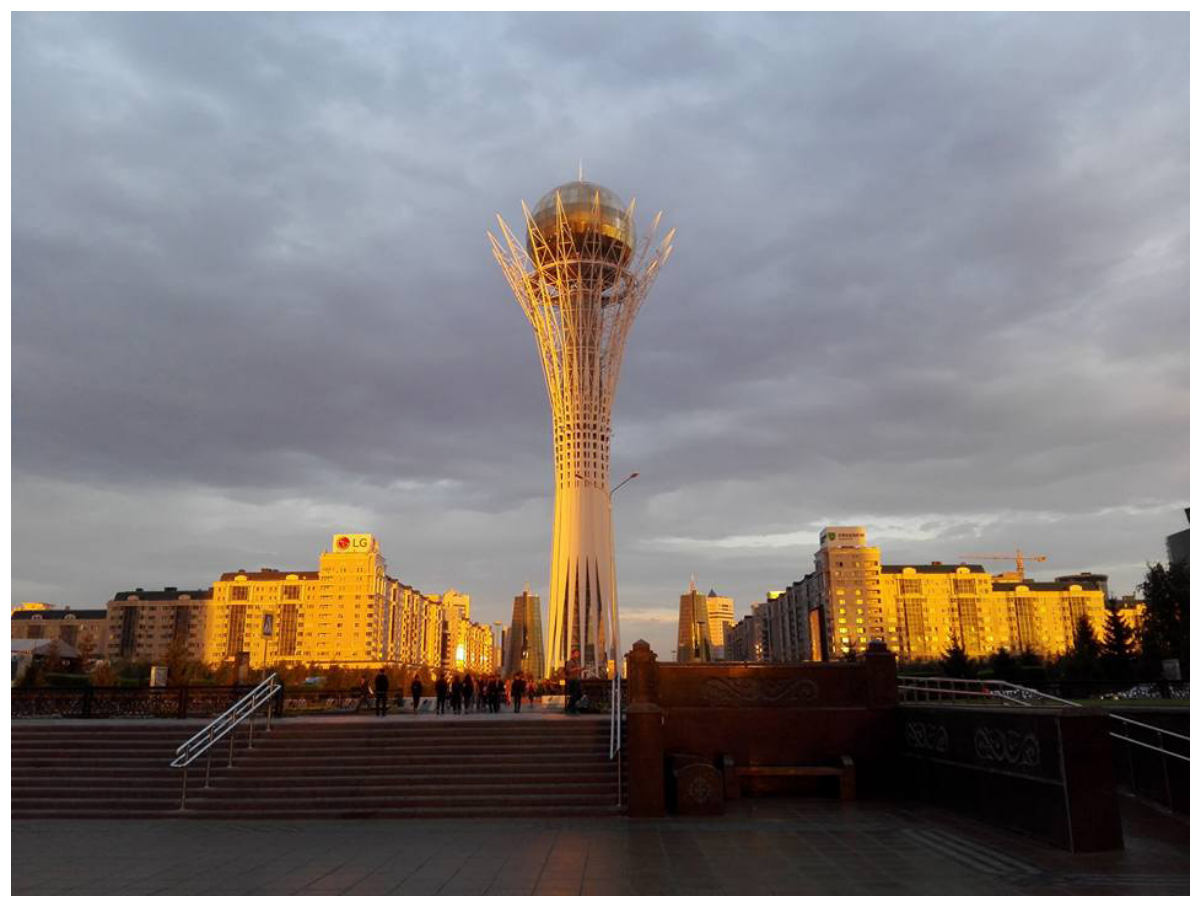

Fot. 7. Wieża Baiterek. Źródło: portal podróżniczy Travelin data [dostęp: 16.09.2018].

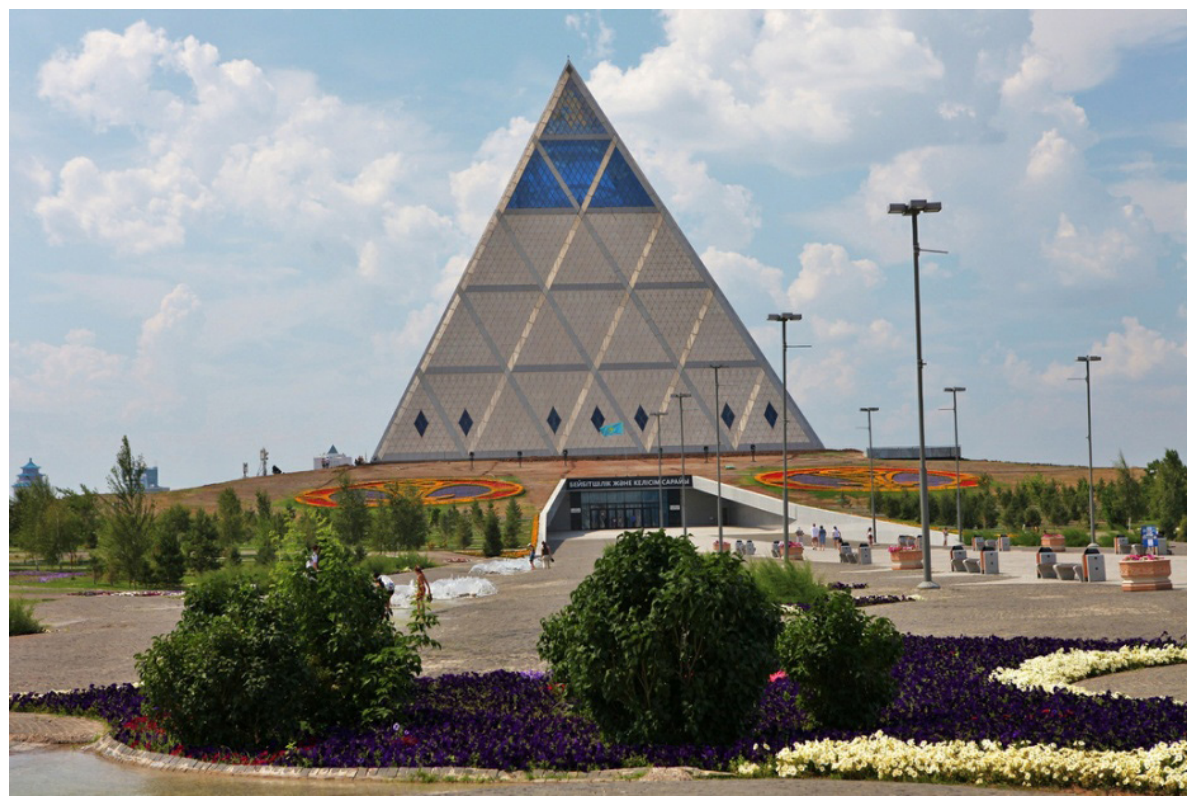

Fot. 8. Piramida Pokoju i Pojednania. Źródło: portal podróżniczy Travelin data [dostęp: 16.09.2018]. 